\title{
Practice and Transmission of Batik in Wukirsari Village, Yogyakarta -Safeguarding Intangible Cultural Heritage in Indonesia-
}

\author{
Ai Fukuda ${ }^{1}$, Yasufumi Uekita ${ }^{2}$, Yoyok Wahyu Subroto $^{3} \&$ Run Zhao ${ }^{4}$ \\ ${ }^{1}$ Master Program in Heritage Studies, University of Tsukuba, Japan \\ ${ }^{2}$ Faculty of Art and Design, University of Tsukuba, Japan \\ ${ }^{3}$ Faculty of Architecture and Planning, Gadjah Mada University, Indonesia \\ ${ }^{4}$ Doctoral Program in Heritage Studies, University of Tsukuba, Japan \\ Correspondence: Ai Fukuda, Heritage Studies, University of Tsukuba, Cooperative Research Building A-204, \\ Tennodai 1-1-1, Tsukuba City, 305-8571, Japan. Tel: +81-90-6422-7352. E-mail: aifncnc@gmail.com
}

Received: January 24, 2021

Accepted: March 31, 2020

Online Published: June 30, 2021

doi:10.5539/ach.v13n1p8

URL: https://doi.org/10.5539/ach.v13n1p8

\begin{abstract}
The target of this research is to figure out the state of practice and transmission of Batik, an Indonesian textile dyeing Intangible Cultural Heritage, and necessary angles for its conservation. Knowledge related to Batik is shared and transmitted in craftspeople communities in Wukirsari Village, which is one of Batik centers in Indonesia. What's more, Batik cloth production organizations play an essential role in the transmission of Batik technique through creating job opportunities, establishing selling systems and so on. Apart from that, these organizations also hold mutual aiding activities, which build strong relationship among craftspeople and support daily life of craftspeople financially. So it is can be concluded that 3 points are necessary for the transmission of Batik culture: building a knowledge-sharing environment, making Batik practice an occupation, offering values beyond financial benefits.
\end{abstract}

Keywords: Intangible Cultural Heritage, Batik, Indonesia, Yogyakarta, Wukirsari Village

\section{Introduction}

In order to safeguard traditional performing arts, craftsmanship and so on, the Convention for the Safeguarding of the Intangible Cultural Heritage was adopted by UNESCO in 2003, entering into force in 2006 and ratified by 180 States until 2020. It is playing an important role together with the Convention Concerning the Protection of the World Cultural and Natural Heritage in the protection activities led by UNESCO. It is said that intangible cultural heritages $(\mathrm{ICH})$ couldn't exist in isolation without bearers, who are related individuals, groups and communities. The importance of bearers, which are deemed essential in the creation, protection, maintenance and renewal of $\mathrm{ICH}$, is emphasized throughout the Convention. In addition, as heritages of great value for indigenous societies, ICH provides important implications for solving the global challenges facing the world today through advocating inherited knowledge and cultural diversity. Thanks to the Convention, the concept of $\mathrm{ICH}$ has been permeating internationally. And great importance has also been attached to the protection of ICH gradually. However, some States are still not equipped with well-designed protection systems.

When it comes to Indonesia, domestic ICH protection has been promoted with achievements of 1,137 cases designated and 9,999 cases recorded by 2020. Nevertheless, concrete action plans for protection has not been established yet. The angles based on which protection plans should be constructed are still under discussion.

The case taken in this paper is a wax-resist dyeing technique of Indonesia, called Batik. Patterns are drawn by a craftsperson with hot wax on a cloth, after dying, boiling water is used to remove the wax, so that some space (the designed patterns) can be left behind without dying. This technique has been inherited in some areas of Java Island, Madura Island and part of Sumatra Island. However, since 1970s, printed cloths, which is cheap and can be mass-produced, have been replacing traditional Batik cloths gradually. In contrast with $90 \%$ market share claimed by printed and dyed cloths, traditional hand-made Batik cloths have long faced a producing slowdown. In view of the situation, Batik technique was inscribed in 2009 on UNESCO's Representative List of the Intangible Cultural Heritage of Humanity, which provided a major impetus for the protection activities. 
Former researches about Batik technique focuses on its history, patterns and technique itself, furthermore, anthropological studies can also be found in recent years. For example, a research conducted by Yoshimoto (1996) analyzed Batik's impacts on other cultures and similarity in design; studies undertaken by Sekimoto (2000) and Agari (2009) revealed the changing process of traditional Batik technique under the influence of modern industrialization; Sekimoto (2003) and Sato (2015) analyzed the relationship between Batik cloths producing communities and market economy. Nevertheless, the discussion of Batik technique's transmission and protection from a heritage angle has not been conducted enough. Actual state of bearers (individuals, communities and so on) and their practice and transmission remain unclear.

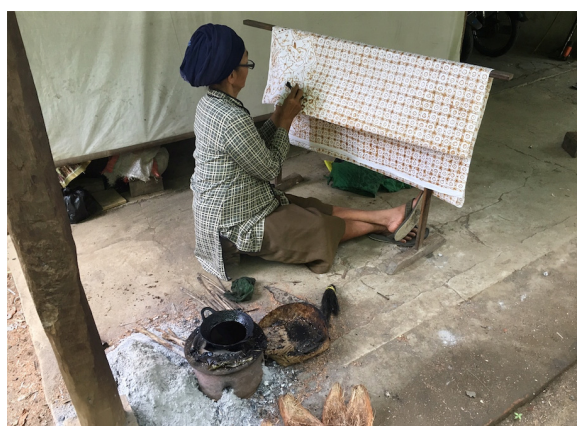

Figure 1 Woman drawing a pattern with wax on cloth

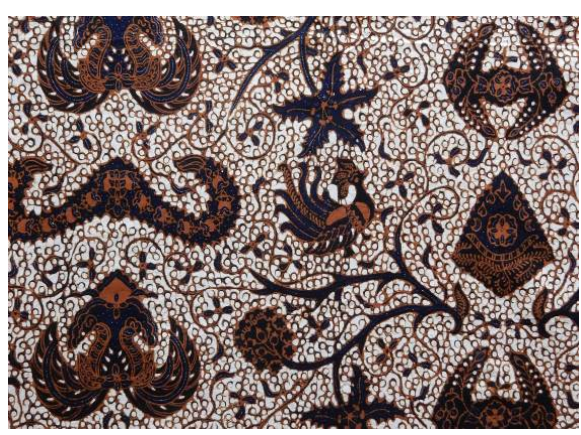

Figure 2 Batik cloth

\section{Objectives}

For the purpose of figuring out perspectives necessary for the persistence of Batik technique, the following 3 points related to Batik technique's practice and transmission in Wukirsari Village, which holds this technique till now, will be made explicit in this article.

(1) the history of Batik and Batik cloth's production system in Wukirsari Village, and the inherited factors

(2) the way and the characteristics of Batik transmission

(3) the characteristics of production systems nowadays and its function in Batik technique's persistence

\section{Area descriptions}

The target site, Wukirsari Village, is located in the Special Region of Yogyakarta (named Daerah Istimewa Yogyakarta in Indonesian), which is on the south coast of Java. Comprising one capital city and four rural regencies, Special Region of Yogyakarta is one of the 34 provinces of Indonesia. And Yogyakarta City is the capital city of Special Region of Yogyakarta, which is also the location of royal palace (named Kraton in Indonesian). The King, called Sultan in Indonesia, and royal family are living in Yogyakarta City with Sultan serving as the governor of the Special Region of Yogyakarta. As an ancient city, Yogyakarta City formed a distinctive culture based on the royal palace. Traditional Batik technique, as a part of royal culture, is inherited in Yogyakarta City and Surakarta City (also known as Solo located in Central Java). In Surakarta City, numerous Batik makers are attempting to transforming to produce printed Batik cloths as a response to modern industrialization. Especially in 1980s, an obvious decrease happened in the engagement of Batik cloths making as a result of wide subcontracting from large companies. In comparison, traditional Batik makers in Yogyakarta City show less interest to change to make printed Batik cloths, so that hand-made Batik cloths persist well there till now. With this background, Yogyakarta City, as a major city of Batik cloths making in Indonesia until now, was designated as World Craft City for Batik by World Crafts Council in 2014. Batik industry, like other hand-made fabric-related industry, is playing a crucial role in females' sideline business as well. Middle and small Batik enterprises, almost traditional hand-made Batik cloths makers gather in some areas, which are called Sentra Batik and scattered in Special Region of Yogyakarta.

Table 1 shows the Batik cloths production areas and number of workers in the Special Region of Yogyakarta based on official statistics from Department of Industry and Trade of the Special Region of Yogyakarta. Three rural regencies (Bantul, Kulonprogo and Gunungkidul) hold the most Batik cloths makers, so that they are deemed indispensable in Batik's practice and transmission.

Wukirsari Village, as one of the eight administrative villages in Imogiri District which is in Bantul Regency, consists of 16 hamlets, 13 kilometers to the southeast of Yogyakarta City, covers 15 square kilometers, and has a population of nearly 17,000 . On the top of hilly areas in the south of the village, there is a traditional resting 
place for the royal family (Makam Imogiri). Craftspeople of Batik in Wukirsari Village almost gather in Karangkulon hamlet, Giriloyo hamlet and Cengkehan hamlet, which are called Kampung Batik Giriloyo in general. Female residents account for the majority of Batik craftspeople, and there are 16 Batik cloths production organization in Kampung Batik Giriloyo as of 2015. In this study, kampung Batik Giriloyo is taken as the specific target site.
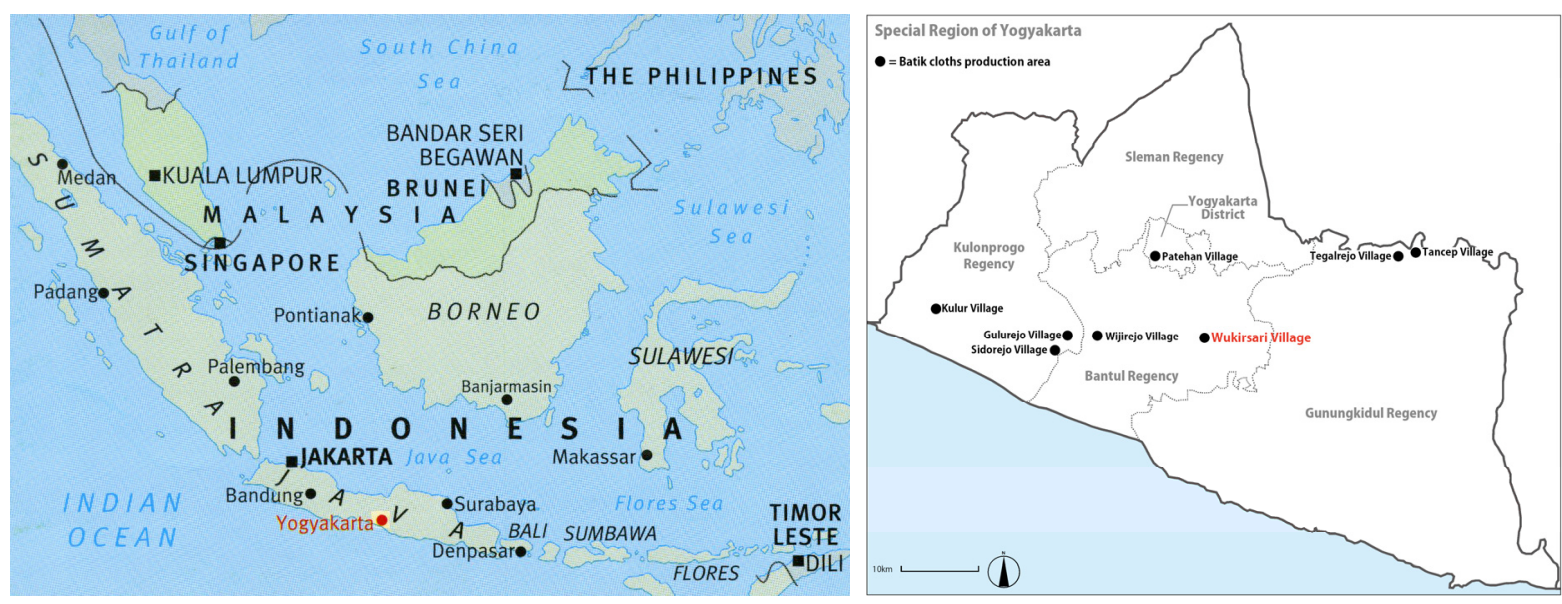

Figure 3 The location of Special Region of Yogyakarta in Indonesia (Source: PERIPLUS)

Figure 4 The location of Wukirsari Village and Batik cloths production areas in Yogyakarta

Table1 Batik cloths production areas and number of workers in Yogyakarta

\begin{tabular}{lcclc}
\hline $\begin{array}{l}\text { Location } \\
\text { Kabpaten/Kota } \\
\text { (District/Regency) }\end{array}$ & $\begin{array}{l}\text { Kecamatan } \\
\text { (Sub-district) }\end{array}$ & $\begin{array}{l}\text { Desa } \\
\text { (Village) }\end{array}$ & $\begin{array}{l}\text { Name } \\
\text { producing } \\
\text { center }\end{array}$ & $\begin{array}{l}\text { of } \\
\text { Nomber }\end{array}$ of \\
\hline \multirow{2}{*}{ Kota Yogyakarta } & Kraton & Patehan & Batik painting & 44 \\
Sleman & Total & & & $\mathbf{4 4}$ \\
& N/A (Not forming production areas) & & \\
Bantul & Imogiri & Wukirsari & Batik & 623 \\
& Pandak & Wijirejo & Batik & 174 \\
& Total & & & $\mathbf{7 9 7}$ \\
Kulonprogo & Temon & Kulur & & 174 \\
& Lendah & Sidorejo & Batik & 158 \\
& Lendah & Gulurejo & Batik & 148 \\
Total & & & $\mathbf{4 8 0}$ \\
& Ngawen & Tancep & Batik & 90 \\
& Gdangsari & Tegalrejo & Batik & 44 \\
\hline
\end{tabular}




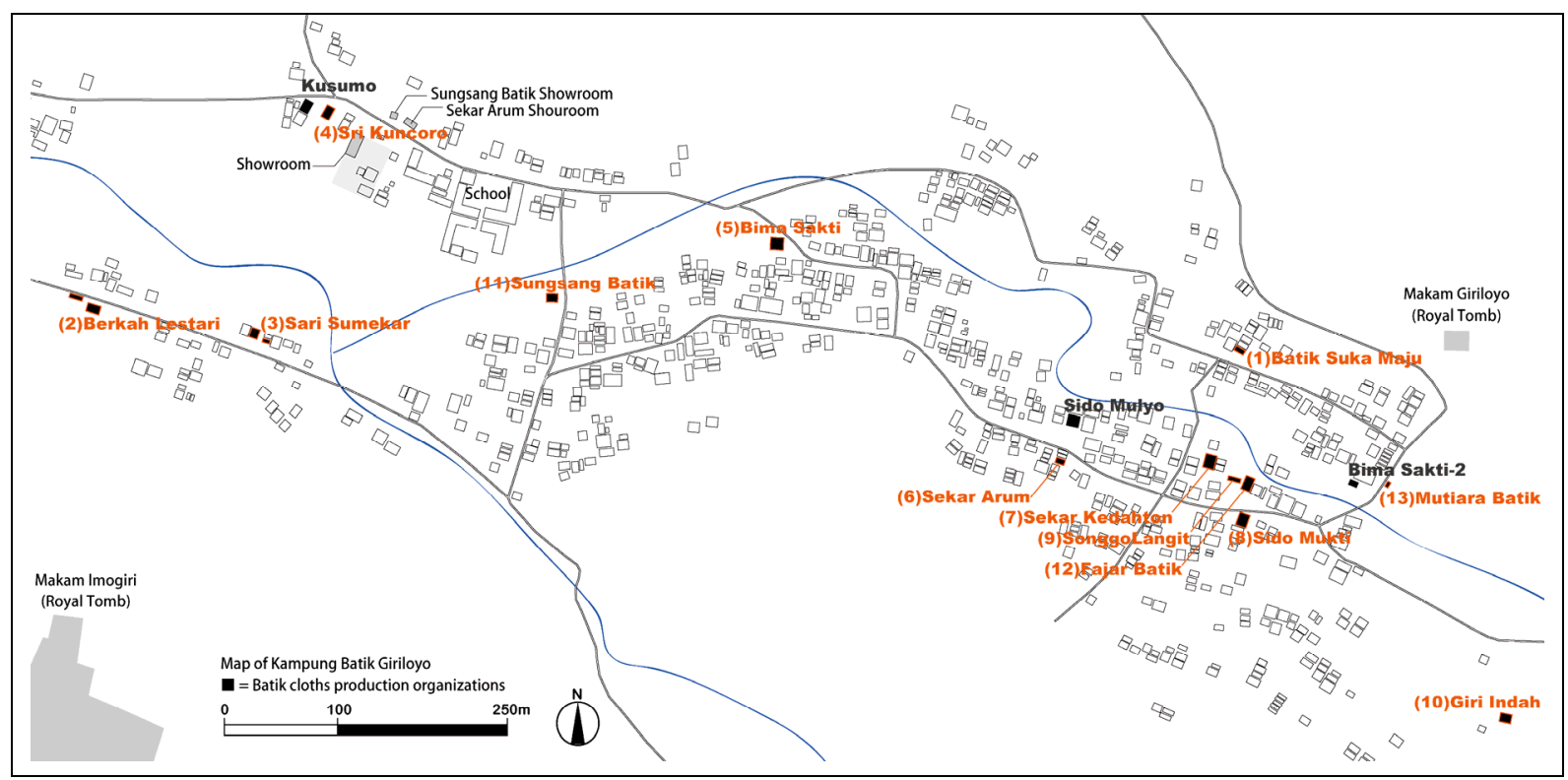

Figure 5 Research area and Batik cloths production organizations in Wukirsari Village

\section{Methodology}

Qualitative research is applied in this research. Literature study is conducted to make Batik's history and culture of target site clear, the change of production system and inherited factors of Batik will also be explicit through this method. What's more, field work approach is used with Batik practitioners and groups as objects. Specifically, semi-structured interview and non-structured interview, questionnaire investigation and participant observation are operated targeting 13 Batik cloths production organizations and individual craftspeople. In June, 2015, there were 16 Batik cloths production organizations in kampung Batik Giriloyo. However, three groups were not taken into consideration because of the suspension in operation, lack of formal operation as a result of fresh establishment and limited operation only responding to regulars' orders. Field work was conducted from April, 2015 to February, 2016, and August, 2016 as an addition. Some data from previous researches was also taken advantage of in this study.

\section{Results}

\subsection{The Transition of Batik in Wukirsari Village}

Analyses related to changes of production system and inherited factors will be used to illustrate the transition of Batik technique in Wukirsari Village.

\subsubsection{Changes of Batik Cloths Production System}

\subsubsection{The Origin and Evolution of Batik Technique (Roya-Family-Based System)}

Even through the origin of Batik has long been discussed, there is a consensus, based on indigenous imperial mausoleums, that it originates from mid-1600s. In order to satisfy requests from palace, Batik cloths production began to be conducted in Pajimatan hamlet, where lived the family of mausoleum guard Abdi Dalem (Sumintarsih, 1990). Wukirsari Village nowadays is almost the area of north Pajimatan hamlet then. As the needs for Batik cloths increased, following the practice of Giriloyo hamlet, villagers from other hamlets turned to make Batik cloths(Sudijono, 2006). What's more, rather than only for royal family, Batik cloths had been made for the family of craftspeople and customers in free market by degrees. Alongside the growth of Batik cloths production, a wholesale-centered domestic industry system came into being, which is an industry system that craftspeople, who borrow materials from wholesalers or merchants, then draw patterns on cloths with wax at home, and get wages with their drawn cloths.

\subsubsection{Evnironmental Changes of Batik Practice in Pace with Modernization (Wholesale-Centered Domestic Industry System)}

Along with the development of tourism in 1970s, Batik industry in Indonesia progressed, the one in Wukirsari Village became prosperous as well. After the prosperity in 1970s, Batik industry began to decrease in the wake of the rapid spread of high-quality printed Batik cloths in 1980s. The employment relationship in hand-made 
Batik cloths industry, which affected by the worsening economic environment, between wholesalers and Batik craftspeople was going from bad to worse. To improve the situation, a Batik cloths production organization called Bima Sakti was set up in 1982, with the support from United Nations Development Programme (UNDP), Japan, Germany and Netherlands, involving the establishment of facilities for dying and wax-removing of Batik cloths (Sudijono, 2006). After that, Bima Sakti was separated into 7 organizations and its activities turned to be hamlet-centered. Since members of Bima Sakti are craftspeople, they shifted to buying wax-drawn cloths and being in charge of practice from dying to selling (Sumintarsih, 1990). However, only minority of Bima Sakti members mastered the whole process of Batik cloths making, majority of the members merely had a command of wax-drawing practice, which was in consequence of the former wholesale-centered domestic industry system (Sumintarsih, 1990). A further slowdown of Batik industry happened after 1998, when Asian Financial Crisis pushed the price of raw materials to surge. It is said that craftspeople in Wukirsari Village had been struggling to survive with shrinking orders. In 2004, a new Batik cloths production organization called Suka Maju was created along with the establishment of production facilities by the Department of Industry and Trade of the Special Region of Yogyakarta.

\subsubsection{Organized Batik Production with a Backgroud of Revival from Earthquake (Organizational Production System)}

In addition to the downturn of Batik industry, an earthquake with a hypocenter in Yogyakarta occurred in the middle of Java in May 2006, which did immense harm to Wukirsari Village. As a major part of the revival plan, the resurgence of Batik industry was paid great attention to, which resulted in the building of Batik cloths production organizations supported by domestic and international funds. Local female craftspeople accounted for the majority of these organizations, which equipped with facilities of dying and wax-removing, where dying, designing and selling management courses were held by the Department of Industry and Trade of the Special Region of Yogyakarta. Thanks to these efforts, each part of the production process of hand-made Batik cloths, especially the process from dying to selling, was integrated into a whole in these organizations, consisting of craftspeople in Wukirsari Village as major members. Nevertheless, since this support was temporary, the operators of these organizations soon turned to craftspeople in the village, and new organizations had been set up since then. From 2007 to 2016, 16 organizations were established. In 2008, a general institute called Paguyuban Batik Tulis Giriloyo, including the former organizations, was founded.

\subsubsection{Inherited Factors of Batik Technique}

As mentioned above, the sequence of Batik cloth's production systems in Wukirsari Village is royal-family-based system, wholesale-centered domestic industry system and organizational production system. Especially after the earthquake in 2006, as a system integrated with a process from dying to selling, organizational production system was set up, which also marked an enormous environmental change happened to Batik practice. According to the comparison of each production system of Batik cloths, as the techniques from dying are merely inherited by a part of craftspeople, so wax-drawing is the only technique that is inherited by every craftsperson till now. Specifically, a hand-made wax-drawing technique centered on using a tool called canting to draw out classical patterns is inherited in Wukirsari Village up to now.

\subsection{The Characteristics and Transmission Methods of Classical Patterns and Wax-Drawing Technique}

\subsubsection{The Transmission of Classical Patterns}

The inherited classical patterns in Wukirsari Village can be traced back to their close connection to royal palace. Two kinds of patterns comprise the classical patterns: one is called main pattern, which is motif pattern manifesting as birds, wings, flowers and so on; the other one is called land pattern, which features in lines and dots, and is drawn within main patterns, between main patterns or in the background. Even through some modern new patterns are created in recent years, more than half of the cloths produced by 11 out of 13 Batik cloth production organizations are drawn with classical patterns, which can be seen as a high ratio.

Classical patterns are inherited based on pattern paper preserved in the home of craftspeople. It is a category of wax paper, 30 to $50 \mathrm{~cm}$ wide and 110 to $115 \mathrm{~cm}$ long, drawn profile lines of motif patterns with a felt-tip pen or a ball-point pen. Craftspeople use pencils or water-based pens to copy patterns from pattern paper to cloths. When it comes to land pattern, craftspeople draw patterns they are good at to cloths directly without pattern paper. Original pattern paper can be duplicated to a new piece of paper if the original one is worn out, and the new one will be passed on from generation to generation within the craft family. In contrast to the limitation of sharing modern pattern paper designed lately between production organizations, the sharing of classical pattern paper is quite common. 


\subsubsection{The Transmission of Wax-Drawing Technique}

The Batik technique practiced in Wukirsari Village, which is called Batik Tulis, is a way to add wax to cloths by hand with the tool canting. Drawing on two sides of the cloths is also an ancient custom inherited till now. Women account for the majority of wax-drawing craftspeople as it was in the past. Wax-drawing, which is taken pattern selection and dying into consideration, includes the drawing of profile lines, the drawing of land patterns, wax-drawing on dye-free part and so on. Although some craftspeople can operate the whole process, division of labor is more often. About five craftspeople is needed to finish the entire operation.

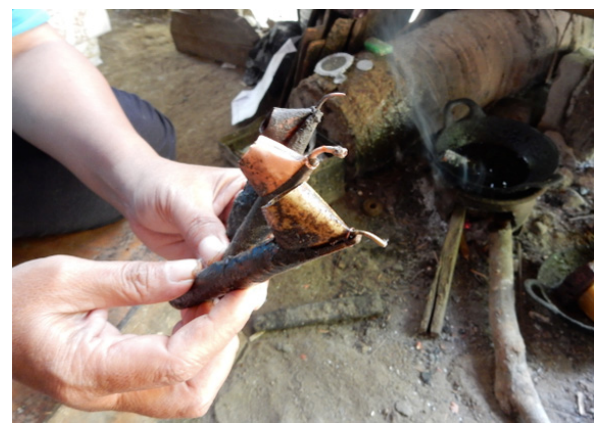

Figure 6 Canting

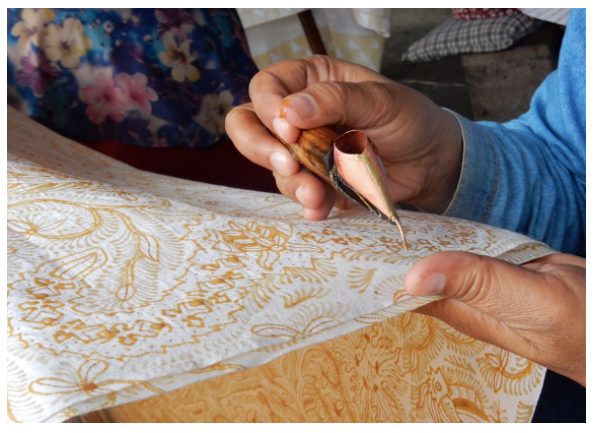

Figure 7 Wax-Drawing

Table 2 shows the results of a questionnaire survey about wax-drawing learning method answered by Batik craftspeople in Wukirsari Village. All of the respondents are females, who live in Wukirsari Village and work at those production organizations. The questionnaire response rate is $100 \%$.

As to the results, about the way of learning wax-drawing technique, most people answered as observing and self-study, no people learn from schools. Normally, wax-drawing is practiced by individual craftsperson or a group of craftspeople at kitchen, house frontage, or roadside. There is half-outdoor space within the workplace set up by production organizations for wax-drawing groups. Working hours and days are decided by craftspeople, who can arrange the work in the spare time of their daily life, for instance the time spared from domestic chores, child rearing and farm work. And children learn wax-drawing technique in this environment from their mother and neighbors by observing the practice in their home and other places in the village, and sometimes by helping their mother in the process.

Table 2 Questionnaire results on method for acquiring skills

\begin{tabular}{|c|c|c|c|}
\hline $\begin{array}{l}\text { Questionnaire } \\
\text { (n=Number of respondents) }\end{array}$ & Answer & $\begin{array}{l}\text { Number of } \\
\text { respondents }\end{array}$ & Percentage \\
\hline \multirow{3}{*}{$\begin{array}{l}\text { 1. How did you learn the wax-drawing technique? } \\
(\mathrm{n}=51)\end{array}$} & $\begin{array}{l}\text { (1) By watching } \\
\text { others }\end{array}$ & 38 & 74.5 \\
\hline & (2) Self-taught & 11 & 21.5 \\
\hline & (3) Others & 2 & 4.0 \\
\hline \multirow{4}{*}{$\begin{array}{l}\text { 2. Who taught you how to do it? }(\mathrm{n}=38) \\
\text { *Only for the person who answered (1) for the } \\
\text { question1 }\end{array}$} & (1) Mother & 31 & 82.0 \\
\hline & (2) Grandmother & 5 & 13.0 \\
\hline & $\begin{array}{l}\text { (3) Mother and } \\
\text { neighbors }\end{array}$ & 1 & 2.5 \\
\hline & (4) Mother and others & 1 & 2.5 \\
\hline
\end{tabular}



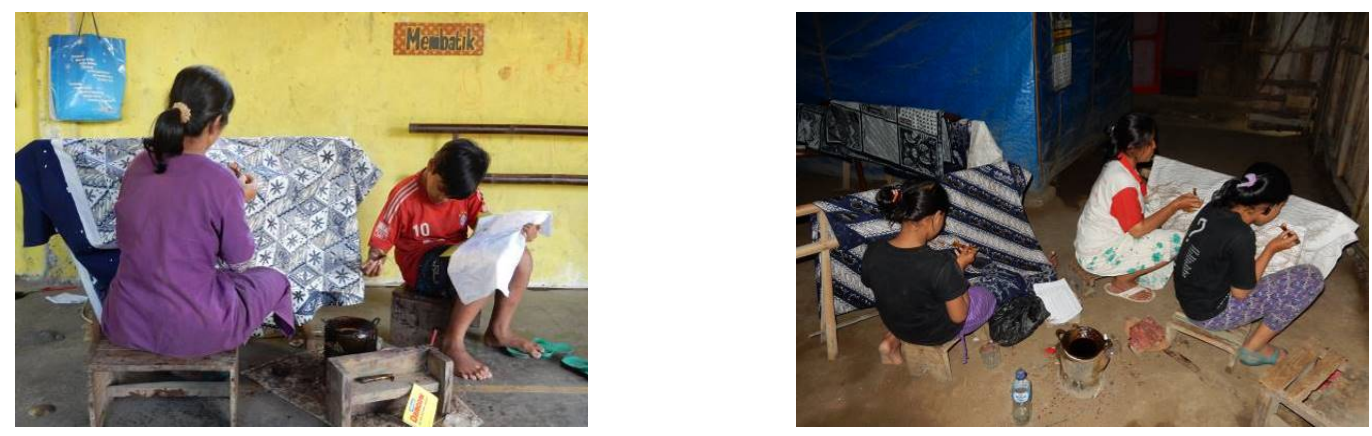

Figure 8 and 9 Mother and child drawing a pattern with wax on cloth

\subsection{Characteristics and Functions of Activities of Batik Cloths Production Organizations}

This article tries to make clear the mechanism and relationship between craftspeople and Batik cloths production organizations, which is the base of Batik production system in today's Wukirsari Village. So that the functions of these organizations in the persistence of Batik will be clear-cut.

\subsubsection{Organizations Related to Batik Production}

\subsubsection{Batik Giriloyo Institute (Paguyuban Batik Tulis Giriloyo)}

Batik Giriloyo Institute, set up in 2008, is an umbrella organization, coordinating the activities of Batik cloths production organizations in dusun Karangkulon hamlet, dusun Giriloyo hamlet and dusun Cengkehan hamlet, which are in Wukirsari Village. Its establishment was a response to the appeal to integrate existing Batik cloths production organizations especially those created after Java earthquake in 2006. Holding more than 10 members and paying membership fee are prerequisites for a Batik cloths production organization to join the institute. 10 out of 13 Batik cloths production organizations are members of the institute now.

Operations of Batik Giriloyo Institute are mainly centered on the implementing of fairs, management of showrooms, order-receiving of Batik cloths and so on. As for fairs, which is hold once a month with representatives from each production organization taking part in, information-sharing, resolving problems through arbitration, receiving orders from institute, division of work about Batik-experiencing workshop and so forth will be done here. What's more, negotiations, without coercion, can also be made here about Batik products' prices in Wukirsari Village, wages of craftspeople and the like. In June, 2016, a showroom was established in a corner of the square in the village, which is operated by the institute and mainly used to sell Batik cloths made by those production organizations. But Batik cloths made by other villagers who are not affiliated to those production organizations and submit selling applications directly to the institute are also acceptable. In regard to order-receiving, the institute divide these orders to each production organization, which further divides the order to its craftspeople members to do the wax-drawing and dying work by turns.

\subsubsection{Batik cloths production organizations}

In contrast to Batik Giriloyo Institute, which does not operate the production of Batik cloths, Batik cloths production organizations are in charge of Batik production, which can be classified into Cooperative Association, Batik Groups and Private Small Businesses.

\section{(a) Cooperative Association (Koperasi)}

Within the 13 Batik cloths production organizations, only Suka Maju is cooperative association, which is set up in 2004 and changed from Batik group to cooperative association in 2008. Suka Maju has 91 members now and is the biggest one amid the 13 organizations. Cooperative association is founded based on relevant laws in Indonesia, which pushes it to keep transparent and fair. A general meeting is hold once a year, in which cooperative association reveal its draft budget, financial report and operation report as an obligation. Furthermore, regular gathering once a month is organized to offer financial support to members and confirm the progress of production among others. In addition, as Batik clothsn production is part of the association's activity, it serves as branch office of labors'health management, called Pos UKK, implementing medical check-up and health consultation together with local health center.

\section{(b) Batik Groups (Kelompok Batik)}

Fundamentally, the operations of Batik groups are based on agreement of members. There are nine Batik groups now, the majority of these groups are started after the earthquake in 2006, except for Bima Sakti. So the 
establishment of these groups, set up on loan completely or partly from cooperative association or other Batik groups, is also part of revival campaign after the earthquake. Each group has 12 to 50 members and holds activities at different frequencies. Active members are in charge of not only Batik practice but also group operation. What's more, most groups keep regular gatherings to share information and offer financial support to members. Craftspeople are paid at piece rates. A part of profit is distributed to members evenly at the end of the year. After purchasing raw materials and paying craftspeople wages, the left profit will be saved and used for public purpose in the future.

\section{(c) Private Small Businesses (Usaha Sendiri)}

There are 3 Batik private small businesses. Since its establishment is based on individual funding, owners have the final say about production and finance. Divergent from cooperative association and Batik groups, some private small businesses don't adopt piece-work system but monthly salary plan, nor profit distribution mechanism, which means after removing salaries paid to craftspeople, cost required for maintenance and management of facility, materials cost and the like, the left profits belong to owners completely. Even though private small businesses have the same production process as cooperative association and Batik groups, patterns on its Batik cloths are distinct. They, such as Sungsang Batik and Mutiara Batik, tend to make modern patterns, and a mixture of classical and modern patterns on a piece of cloth is common, like cloths exhibited in showrooms.

\subsubsection{The System of Batik Cloths Production Organizations}

\subsubsection{Batik-Production-Organizations-Centered Batik Practice}

About $60 \%$ craftspeople in Wukirsari Village are affiliated to those Batik cloths production organizations. Table 3 shows the results of a semi-structured interview with the 13 Batik cloths production organizations about their functions in Batik-cloth-making. Firstly, they give work to craftspeople as well as provide raw materials, for example cloths and waxes. Craftspeople can work from home in the time spared from household cares, childcare or farm work, who can also do the wax-drawing in a group in working space offered by organizations. Cloths drawn patterns will be returned to organizations to finish the dying and wax-removing process, which will be done after wax-drawing at an interval of one week to one month. Finished Batik cloths will be exhibited in showrooms, hold by one organization's own, other organizations or all of the organizations, as well as at Batik fairs in city, for selling.

Batik cloths production organizations are considered significant for Batik practice to make not only a profit-sharing mechanism, which is almost in cooperative association and Batik group, but also an order-based production mechanism, as well as a showroom-based production mechanism from selling through showrooms to production for stock replenishment. Order-based production merely accounts for half or less of Batik cloths production in 10 out of 13 organizations, which prefer selling Batik cloths through showrooms. But the founding of a system from production to selling makes sustainable Batik practice possible.

\subsubsection{Craftspeople's Role in the Batik-Production-Organizations-Centered Batik Practice}

Craftspeople receive cloths and waxes from Batik cloths production organizations, then distribute specific wax-drawing procedures to individuals, during which process there is no intervention of organizations, and return finished Batik cloths to organizations to get wages. What's more, as a sideline, wax-drawing is always done from home in their spare time. According to interview with craftspeople, the bulk of them do this work almost on a daily basis, and decide working time by themselves, who think of family and local events as priorities.

Wax-drawing technique is inherited through observing mother's work at home and practice this work by children, during which process there is no intervention of organizations. What's more, a few craftspeople prepare cloths and waxes by themselves and sell wax-drawing-finished cloths to organizations, who continue to operate the dying and wax-removing process before selling the cloths through showrooms. 
Table 3 The questionnaire results on method for acquiring skills

\begin{tabular}{|c|c|c|c|c|c|c|c|c|c|c|c|c|c|}
\hline $\begin{array}{l}\text { Forms } \\
\text { Organizations }\end{array}$ & $\begin{array}{l}\text { Cooperativ } \\
\mathrm{e} \\
\text { Associatio } \\
\mathrm{n}\end{array}$ & \multicolumn{9}{|c|}{$\begin{array}{l}\text { Batik Groups } \\
\text { (Kelompok Batik) }\end{array}$} & \multicolumn{3}{|c|}{$\begin{array}{l}\text { Private Small Businesses } \\
\text { (Usaha Sendiri) }\end{array}$} \\
\hline No. & 1 & 2 & 3 & 4 & 5 & 6 & 7 & 8 & 9 & 10 & 11 & 12 & 13 \\
\hline $\begin{array}{l}\text { Names } \\
\text { Organizations }\end{array}$ & Suka Maju & $\begin{array}{l}\text { Berkah } \\
\text { Lestari }\end{array}$ & $\begin{array}{l}\text { Sari } \\
\text { Sumekar }\end{array}$ & $\begin{array}{l}\text { Sri } \\
\text { Kuncoro }\end{array}$ & $\begin{array}{l}\text { Bima } \\
\text { Sakti }\end{array}$ & $\begin{array}{l}\text { Sekar } \\
\text { Arum }\end{array}$ & $\begin{array}{l}\text { Sekar } \\
\text { Kedhaton }\end{array}$ & $\begin{array}{l}\text { Sido } \\
\text { Mukti }\end{array}$ & $\begin{array}{l}\text { Songgo } \\
\text { Langit }\end{array}$ & $\begin{array}{l}\text { Giri } \\
\text { Indah }\end{array}$ & $\begin{array}{l}\text { Sungsang } \\
\text { Batik }\end{array}$ & $\begin{array}{l}\text { Fajar } \\
\text { Batik }\end{array}$ & $\begin{array}{l}\text { Mutiara } \\
\text { Batik }\end{array}$ \\
\hline $\begin{array}{l}\text { Location } \\
\text { (hamlet) }\end{array}$ & $\begin{array}{l}\text { Cengkeha } \\
\mathrm{n}\end{array}$ & $\begin{array}{l}\text { Karangkulo } \\
\mathrm{n}\end{array}$ & $\begin{array}{l}\text { Karangkul } \\
\text { on }\end{array}$ & $\begin{array}{l}\text { Karangkulo } \\
\mathrm{n}\end{array}$ & $\begin{array}{l}\text { Karangku } \\
\text { lon }\end{array}$ & Giriloyo & Giriloyo & Giriloyo & Giriloyo & $\begin{array}{l}\text { Cengkeha } \\
\mathrm{n}\end{array}$ & $\begin{array}{l}\text { Karangkul } \\
\text { on }\end{array}$ & Giriloyo & $\begin{array}{l}\text { Cengkeha } \\
\mathrm{n}\end{array}$ \\
\hline $\begin{array}{l}\text { Year } \\
\text { Establishment }\end{array}$ & $\begin{array}{l}2004 \\
\text { (Became } \\
\text { Koperasi } \\
\text { in 2008) }\end{array}$ & 2007 & 2007 & 2008 & 1982 & 2007 & 2008 & 2008 & 2010 & 2009 & 2007 & 2011 & 2012 \\
\hline $\begin{array}{l}\text { If Affiliated to } \\
\text { Institute }\end{array}$ & Yes & Yes & Yes & Yes & Yes & Yes & Yes & Yes & No & Yes & Yes & No & No \\
\hline $\begin{array}{l}\text { Number } \\
\text { Members }\end{array}$ & 91 & 50 & 23 & 20 & 30 & 30 & 25 & 26 & 12 & 20 & 30 & about 20 & 8 \\
\hline $\begin{array}{l}\text { Membership Fees } \\
\text { (person monthly) }\end{array}$ & Rp. 5.000 & Rp. 1.000 & Rp. 5.000 & 0 & 0 & 0 & 0 & 0 & Rp. 10.000 & Rp. 3.000 & - & - & - \\
\hline $\begin{array}{l}\text { Usage of } \\
\text { Membership Fees }\end{array}$ & $\begin{array}{l}\text { Simpan- } \\
\text { pinjam }\end{array}$ & $\begin{array}{l}\text { Simpan- } \\
\text { pinjam }\end{array}$ & $\begin{array}{l}\text { Simpan- } \\
\text { pinjam \& } \\
\text { Distributin } \\
\mathrm{g} \text { to } \\
\text { Members } \\
\text { Once a } \\
\text { Year }\end{array}$ & - & - & - & - & - & $\begin{array}{l}\text { Simpan- } \\
\text { pinjam }\end{array}$ & $\begin{array}{l}\text { Raw } \\
\text { Materials }\end{array}$ & - & - & - \\
\hline $\begin{array}{l}\text { Facility } \\
\text { (1)Wax- } \\
\text { Drawing } \\
\text { Workplace } \\
\text { (1) means hardly } \\
\text { used } \\
\text { (2) Dying and } \\
\text { Wax- } \\
\text { Removing } \\
\text { Workplace } \\
\text { (3)Showroom }\end{array}$ & (1) (2) (3) & (1)(2)(3) & (1) (2) (3) & (1)(2) (3) & (2) (3) & (1) (2) 3 & (1) (2) (3) & (1)(2)(3) & No & (1) (2) 3 & (1)(2)(3) & (1) (2) 3 & (2) 3 \\
\hline $\begin{array}{l}\text { Frequency of } \\
\text { Dying }\end{array}$ & $\begin{array}{l}\text { Once Ten } \\
\text { Pieces are } \\
\text { Gathered }\end{array}$ & $\begin{array}{l}\text { About } \\
\text { Once a } \\
\text { Week }\end{array}$ & $\begin{array}{l}\text { Depend on } \\
\text { Orders }\end{array}$ & $\begin{array}{l}\text { Once } 5 \text { to } \\
\text { Ten Pieces } \\
\text { are } \\
\text { Gathered }\end{array}$ & $\begin{array}{l}\text { About } \\
\text { Once } \\
\text { Two } \\
\text { Months }\end{array}$ & $\begin{array}{l}\text { About } \\
\text { Once a } \\
\text { Month }\end{array}$ & $\begin{array}{l}\text { About } \\
\text { Once a } \\
\text { Month }\end{array}$ & $\begin{array}{l}\text { About } \\
\text { Once a } \\
\text { Month }\end{array}$ & $\begin{array}{l}\text { About } \\
\text { Once a } \\
\text { Month }\end{array}$ & $\begin{array}{l}\text { Once Ten } \\
\text { Pieces are } \\
\text { Gathered }\end{array}$ & $\begin{array}{l}\text { Almost } \\
\text { Everyday }\end{array}$ & $\begin{array}{l}\text { Once } 7 \text { to } \\
8 \quad \text { Pieces } \\
\text { are } \\
\text { Gathered }\end{array}$ & $\begin{array}{l}\text { Once Ten } \\
\text { Pieces are } \\
\text { Gathered }\end{array}$ \\
\hline $\begin{array}{l}\text { Frequency of } \\
\text { Wax- } \\
\text { Removing }\end{array}$ & $\begin{array}{l}\text { When } \\
\text { Dying }\end{array}$ & $\begin{array}{l}\text { When } \\
\text { Dying }\end{array}$ & $\begin{array}{l}\text { When } \\
\text { Dying }\end{array}$ & $\begin{array}{l}\text { When } \\
\text { Dying }\end{array}$ & $\begin{array}{l}\text { When } \\
\text { Dying }\end{array}$ & $\begin{array}{l}\text { When } \\
\text { Dying }\end{array}$ & $\begin{array}{l}\text { When } \\
\text { Dying }\end{array}$ & $\begin{array}{l}\text { When } \\
\text { Dying }\end{array}$ & $\begin{array}{l}\text { When } \\
\text { Dying }\end{array}$ & $\begin{array}{l}\text { When } \\
\text { Dying }\end{array}$ & $\begin{array}{l}\text { Once a } \\
\text { Week }\end{array}$ & $\begin{array}{l}\text { When } \\
\text { Dying }\end{array}$ & $\begin{array}{l}\text { When } \\
\text { Dying }\end{array}$ \\
\hline $\begin{array}{l}\text { Percentage of } \\
\text { Order-Based } \\
\text { Production }\end{array}$ & $10 \%$ & $60 \%$ & $70 \%$ & $25 \%$ & 0 & $\begin{array}{l}\text { More } \\
\text { Than } 50 \%\end{array}$ & $50 \%$ & $\begin{array}{l}\text { Less Than } \\
50 \%\end{array}$ & 0 & $5-10 \%$ & $35 \%$ & $10 \%$ & $10 \%$ \\
\hline $\begin{array}{l}\text { Percentage of } \\
\text { Classical Patterns } \\
\text { Production }\end{array}$ & $\begin{array}{l}\text { More } \\
\text { Than } 50 \%\end{array}$ & $\begin{array}{l}\text { More Than } \\
50 \%\end{array}$ & $\begin{array}{l}\text { More } \\
\text { Than } 50 \%\end{array}$ & $\begin{array}{l}\text { More Than } \\
50 \%\end{array}$ & $100 \%$ & $\begin{array}{l}\text { More } \\
\text { Than } 50 \%\end{array}$ & $50 \%$ & $\begin{array}{l}\text { Less Than } \\
50 \%\end{array}$ & $\begin{array}{l}\text { More } \\
\text { Than } 50 \%\end{array}$ & $50 \%$ & $\begin{array}{l}\text { Less Than } \\
50 \%\end{array}$ & $\begin{array}{l}\text { More } \\
\text { Than } 50 \%\end{array}$ & $50 \%$ \\
\hline $\begin{array}{l}\text { Who Decide the } \\
\text { Motif to Produce }\end{array}$ & $\begin{array}{l}\text { Representa } \\
\text { tive or } \\
\text { Individual } \\
\text { Craftspers } \\
\text { on }\end{array}$ & $\begin{array}{l}\text { Collective } \\
\text { Decision- } \\
\text { Making }\end{array}$ & $\begin{array}{l}\text { Individual } \\
\text { Craftspers } \\
\text { on }\end{array}$ & $\begin{array}{l}\text { Collective } \\
\text { Decision- } \\
\text { Making }\end{array}$ & $\begin{array}{l}\text { Represent } \\
\text { ative }\end{array}$ & $\begin{array}{l}\text { Representa } \\
\text { tive }\end{array}$ & $\begin{array}{l}\text { Represent } \\
\text { ative }\end{array}$ & $\begin{array}{l}\text { Members } \\
\text { in Charge } \\
\text { of } \\
\text { Designing }\end{array}$ & $\begin{array}{l}\text { Representa } \\
\text { tive }\end{array}$ & 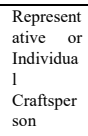 & $\begin{array}{l}\text { Represent } \\
\text { ative }\end{array}$ & $\begin{array}{l}\text { Representa } \\
\text { tive }\end{array}$ & $\begin{array}{l}\text { Represent } \\
\text { ative }\end{array}$ \\
\hline $\begin{array}{lr}\text { Percentage } & \text { of } \\
\text { Members } & \text { Who } \\
\text { Affiliated } & \text { to } \\
\text { Several } & \\
\text { Organizations } & \end{array}$ & $\begin{array}{l}\text { About } \\
60 \% \\
\text { (About } 30 \\
\text { People) }\end{array}$ & About $15 \%$ & $\begin{array}{l}\text { About } \\
65 \% \\
(15 \\
\text { People })\end{array}$ & $\begin{array}{l}\text { About } 15 \% \\
\text { (3 People) }\end{array}$ & $\begin{array}{l}\text { About } \\
27 \% \\
\text { (About } 8 \\
\text { People) }\end{array}$ & $\begin{array}{l}\text { About } \\
17 \% \\
\text { (About } 5 \\
\text { People) }\end{array}$ & 0 & $\begin{array}{l}\text { About } \\
19 \% \\
\text { (About } 5 \\
\text { People) }\end{array}$ & $\begin{array}{l}\text { About } \\
17 \% \\
(2 \text { People) }\end{array}$ & $\begin{array}{l}\text { About } \\
90 \% \\
(18 \\
\text { People })\end{array}$ & 0 & $\begin{array}{l}\text { About } \\
50 \% \\
\text { (About } 10 \\
\text { People) }\end{array}$ & $100 \%$ \\
\hline $\begin{array}{l}\text { If There are } \\
\text { Activities } \\
\text { Unrelated to Batik } \\
\text { (Gathering or } \\
\text { Arisan) }\end{array}$ & $\begin{array}{l}\text { Yes } \\
\text { (Once a } \\
\text { Month) }\end{array}$ & $\begin{array}{l}\text { Yes } \\
\text { (Once a } \\
\text { Month) }\end{array}$ & $\begin{array}{l}\text { Yes } \\
\text { (Once a } \\
\text { Month) }\end{array}$ & $\begin{array}{l}\text { Yes } \\
\text { (Once a } \\
\text { Year) }\end{array}$ & $\begin{array}{l}\text { Yes } \\
\text { (Once a } \\
\text { Month) }\end{array}$ & $\begin{array}{l}\text { Yes } \\
\text { (Once } 35 \\
\text { days) }\end{array}$ & $\begin{array}{l}\text { Yes } \\
\text { (Twice a } \\
\text { Month) }\end{array}$ & $\begin{array}{l}\text { Yes } \\
\text { (Once } \\
\text { Two } \\
\text { Weeks) }\end{array}$ & $\begin{array}{l}\text { Yes } \\
\text { (Once a } \\
\text { Month) }\end{array}$ & $\begin{array}{l}\text { Yes } \\
\text { (Once a } \\
\text { Month) }\end{array}$ & Yes & No & No \\
\hline $\begin{array}{l}\text { If There are } \\
\text { Activities } \\
\text { Unrelated to Batik } \\
\text { (Simpan-pinjam) }\end{array}$ & Yes & Yes & Yes & No & $\begin{array}{l}\text { No } \\
\text { (But } \\
\text { There is } \\
\text { Loan } \\
\text { Mechanis } \\
\text { m) }\end{array}$ & No & No & Yes & Yes & No & No & No & No \\
\hline
\end{tabular}

\subsubsection{Relationship-Building among Batik Cloths Production Organizations and Craftspeople}

\section{(a) Relationship between Organizations and Craftspeople}

Being affiliated to several Batik cloths production organizations at the same time is common for craftspeople in Wukirsari Village, who can also move freely between organizations. Craftspeople are allowed to take work from other organizations if work load of their own organization is not heavy. Even if craftspeople have no affiliation 
to any organization, they can still take work from organizations and sell wax-drawing-finished cloths back to organizations.

\section{(b) Relationship among Organizations}

Consignment sale, order sharing, pattern paper sharing and so on are common among those organizations. For example, a Batik group, located in outback of a hamlet, entrusts cloth sale to another group, which is located in the entrance of the hamlet, a place easy to be seen by visitors. As to order sharing, if one organization received orders overly, it would share part of the orders with others. What's more, if there is a Batik-experience-based workshop for tourists in shared showroom, each organization would send some craftspeople to the workshop as instructors. In addition, Batik Giriloyo Institute often distributes orders and direct collaborative production by plural organizations.

\section{(c) Relationship among Craftspeople}

Relationship-building among craftspeople continues in the production system centered on organizations. According to interviews with craftspeople, who are gathered together to practice Batik by current production system, conversations about Batik among craftspeople, not only the ones during working together but also during exhibiting cloths in shared showrooms as well as instructing Batik-experience-based workshop increased compared to the time of wholesale-centered domestic industry system, the same as colleague activities, whose increase enhanced the relationship among craftspeople. As boundaries among organizations are not clear, relations with other organizations or other craftspeople have become closer compared to the time before.

\subsubsection{Mutual Assistance among Batik Cloths Production Organizations}

Mutual assistance activities, Arisan and Simpan-pinjam, are the characteristics of Batik cloths production organizations in Wukirsari Village.

\subsubsection{Outlines and Features of Mutual Assistance Activities}

\section{(a) Arisan}

Arisan is operated during regular gathering hold by Batik cloths production organizations. It is a mechanism that operates based on reserve funds collected from members regularly, in which each member can receive the funds only once in a whole round and in a lottery-decided sequence. This mechanism is commonplace in Indonesia among relatives, in women's associations, young people's associations and so on. Apart from a fund raising method, Arisan also offer opportunities for people to communicate with one another, so it is said to has aspects of friendliness and entertainment (Narumi, 1993).

\section{(b) Simpan-Pinjam}

Simpan-Pinjam means deposit (simpan) and loan (pinjam). Simpan-Pinjam is an informal credit mechanism that funds of an organization, raised from affluent members or profits of the organization, are lent to members, who need to pay some interest at first. In Wukirsari Village, Batik groups which operate Simpan-Pinjam don't limit the use of lent funds, besides Batik-related consumption, members can use these funds to pay for daily life expenses such as children's educational expenses.

\subsubsection{Functions of Arisan and Simpan-Pinjam}

Arisan is implemented in 9 out of 10 Batik cloths production organizations, which include cooperative association and Batik groups, and Simpan-Pinjam is implemented in 5 organizations. Apart from economic function, they also act as Gotong Royong, a practice of mutual aid, and a role to reinforce the establishment and harmony of communities (Geertz, 1962)(Kuroyanagi, 2001)(Narumi, 1993).

In addition, Simpan-Pinjam can be employed to start a new organization. For example, after learning the knowledge about Batik technique and organization management, members are permitted to set up a new Batik organization with financial support from Simpan-Pinjam. According to interviews with members, receiving shared profits once a year and participating in mutual aid activities like Arisan and Simpan-Pinjam simultaneously are emphasized. And the funds gained from mutual aid activities are especially helpful to alleviate the stress of emergency expenses and daily life expenses. As mentioned above, it can be said that mutual aid activities, which did not exist among craftspeople in Wukirsari Village before the establishment of cooperative association and Batik groups, play important roles in financial supporting as well as forming and strengthening relationship among craftspeople. 


\section{Discussion and Conclusion}

Production and distribution systems of Batik cloths in Wukirsari Village changed from royal-family-based system, wholesale-centered domestic industry system and organizational production system. Wax-drawing is the part of Batik technique inherited till now. As a symbol of royal culture, classical patterns together with the use of the tool canting during wax-drawing process by hand are the key factors kept so far. Pattern paper, as the vehicle of classical patterns, is inherited within each craftsperson's family but shared among craftspeople in the village. What's more, by observing Batik practice of their mother and neighbors, as well as practicing Batik technique in person, children master the technique finally. So it can be concluded that knowledge-sharing and practicing systems of Batik technique based on related craftspeople communities are important to the transmission of this technique.

Thanks to work, raw materials and distribution channels offered by Batik cloths production organizations, Batik cloths making has become a formal occupation of craftspeople. Organizations also hold mutual aid activities such as Arisan and Simpan-Pinjam, which not only support craftspeople's daily life to some extent but also help to augment the relationship among craftspeople. It is summarized that Batik cloths production organizations are important to the practice of Batik technique by offering related occupation, further assisting craftspeople's living financially to a certain extent and enhancing the relationship among craftspeople.

Even though Batik cloths production organizations are important for the practice and transmission of Batik technique, but they are not the sufficient condition, because this technique was also inherited in the past when royal-family-based system and wholesale-centered domestic industry system rather than organizational production system existed. So the point is, even though production and circulation systems are changing with the passage of time, the existence of these systems are essential to guarantee the practice of Batik technique.

As the history of the organizational production system in Wukirsari Village is just 15 years, it is hard to evaluate the effects of this system completely nowadays, further survey is needed in the future. As a system formed after the earthquake in 2006 and benefited from outer financial assistance, controllers of Batik cloths production organizations transferred from non-craftspeople to craftspeople in Wukirsari Village. In addition, organizational production system revived some Batik practice, which nearly disappeared in the past. So it can be said that organizational production system is adaptable in current social environment in Wukirsari Village, and maybe adaptable in other Batik practice areas. There are three necessary points for Batik practice and transmission summarized from the case study of Batik practice in Wukirsari Village:

The first point is creating an environment for sharing. Craftspeople in Wukirsari Village are ready to share, such as to share classical pattern paper among craftspeople, who have collections of classical pattern paper from their ancestors. What's more, there is no formal learning system of wax-drawing technique, as wax-drawing practice is within daily life of every craftsperson, and children, the future Batik craftspeople, can learn this technique by observing it at home or in public space of the village and practicing it in person. From this case study, community rather than family, plays an essential role in the preservation of Batik technique. So it is necessary to take the basic viewpoint of the continuation of practical activities on a community level, not on individual or family units.

The second point is trying to make Batik practice an occupation. Making Batik practice an occupation is a way to give craftspeople an opportunity to practice Batik technique sustainably. As merely holding the knowledge of this technique is far from enough, transmission is unimaginable without sustainable practice, and taking Batik practice as an occupation is an important condition during this process. For the protection of Batik technique, continuing practice of craftspeople has been emphasized, which highlights the necessity of considering Batik technique as a traditional industry.

The third point is offering values beyond financial benefits. As a commodity, it is possible for Batik cloths to find no sale someday, which could lead to the recession of Batik technique. In Wukirsari Village, organizational production system supports craftspeople's living financially and strengthens the relationship among them by holding mutual aid activities, which provide values exceeding economic benefits and help to make an advantageous environment for the transmission of Batik technique.

\section{Acknowledgments}

This research is supported by INPEX scholarship foundation.

\section{References}

Hariyani, S., Antariksa, A., \& Pratomo, A. S. (2006). Pelestarian Kawasan Kampung Batik Laweyan Kota Surakarta. DIMENSI: Journal of Architecture and Built Environment, 34(2), 93-105. 
Clifford Geertz (1960). The Religion of Java. The University Chicago Press.

Sudijono, S. (2006). Pasang Surut Batik Tulis Tradisional Bantul, Studi Kasus Batik Tulis Imogiri Tahun 1970-1998. dalam Patra-Widya, 7(3), 1-47.

Sumintarsih (1990). Pembatik Girilaya Desa Wukirsari Imogiri. Buletin Jarahnitra, Departemen Pendidikan dan Kebudayaan Direktorat Jenderal Kebudayaan Balai Kajian Sejarah dan Nilai Tradisional Yogyakarta. pp3-41.

Agari, H. (2009). Transition and contemporary manual work in Indonesian Batik. Asian Studies, 4, 1-19. (in Japanese)

Sato Junko (2015). Wage Work-Supported Community and Its Limitations: A Case of Batik Work in Central Java. Asia Pacific Review, (12), 38-50. (in Japanese)

Sekimoto Teruo (2000). A Marginalized Tradition: Batik and Javanese Modernity. The Japanese journal of ethnology, 65(3), 268-284. (in Japanese)

Sekimoto Teruo (2003). Market and community: Javanese Batik and its social foundation. Institute for Advanced Studies on Asia. University of Tokyo Press. pp.457-484. (in Japanese)

Narumi Kunihiro, Ardi P. Parimin \& Tahara Naoki (1993). Villages living with the gods in the city of the royal palace. Gakugei Shuppan Sha. (in Japanese)

Yoshimoto Shinobu (1996). Java Sarasa. Heibon Sha. (in Japanese)

\section{Copyrights}

Copyright for this article is retained by the author(s), with first publication rights granted to the journal.

This is an open-access article distributed under the terms and conditions of the Creative Commons Attribution license (http://creativecommons.org/licenses/by/4.0/). 